Vol. 11 (3): 507-514 (2021)

\title{
ENERGY EFFICIENCY RESULTING FROM THE CONSTRUCTION OF THE NEW PERIMETER WALLS OF THE FORMER DAJTI HOTEL IN TIRANA, ALBANIA
}

\author{
Julian Kasharaj $^{1 *}$, Igli Kondi ${ }^{1}$, Dora Foti ${ }^{2}$, Michela Lerna ${ }^{2}$ \\ ${ }^{1 *}$ Polytechnic University of Tirana, Tirana, Albania; \\ ${ }^{2}$ Polytechnic University of Bari, Italy;
}

*Corresponding Author Julian Kasharaj, e-mail: jkasharaj69@yahoo.ca; i.kondi13@gmail.com; dora.foti@poliba.it; michela.lerna@poliba.it

Received March 2021; Accepted April 2021; Published June 2021;

DOI: https://doi.org/10.31407/ijees11.321

\begin{abstract}
The former Dajti Hotel building was at the stage of structure retrofitting works when the earthquake of 26.11.2019 struck Tirana and Durrës (Albania). Some serious damages or destruction of non-structural brick walls were found in the building. The authors of this article provided relevant solutions for the implementation of new earthquakeresistant walls, which, among other things, improve the energy efficiency of the building, besides the safety of nondestruction. This paper focuses concretely and in a detailed way on the improvement of the building's energy efficiency as a result of the proposed way for the realization of the perimeter walls in the building of the former hotel Dajti, Tirana.
\end{abstract}

Keywords: earthquake in Albania 26.11.2019, non-structural brick walls, the former Dajti Hotel building, energy efficiency improvement 